\title{
Vegetation and climate changes in the forest of Campinas, São Paulo State, Brazil, during the last 25,000 cal yr BP
}

\author{
Adriana Mercedes Camejo Aviles ${ }^{*}$ (D), Fresia Ricardi-Branco² (D), \\ Marie-Pierre Ledru ${ }^{3}$ (D) Luís Carlos Bernacci ${ }^{4}$ (D)
}

\begin{abstract}
A paleoenvironmental reconstruction was performed in a Riparian Forest near Campinas to improve knowledge of paleoclimate and paleoenvironment in the State of São Paulo, Brazil. A sediment core of $182 \mathrm{~cm}$ depth was collected in a swamp located within a Cerrado/Seasonal Semi-deciduous ecotone forest. The chronological frame is given by eight radiocarbon dating methods. Pollen and stable isotope analyses $(\delta$ ${ }^{13} \mathrm{C}$ and $\delta^{15} \mathrm{~N}$ ) were performed all along the core. Modern pollen rain is based on five surface samples collected along the Riparian Forest. Results show a sequence of changes in vegetation and climate between 25 and 13 cal kyr before present (BP), and from 4 cal kyr BP to the present time, with a hiatus between 11 and $4 \mathrm{kyr}$ cal BP. Drier climatic conditions characterized the late Pleistocene and early Holocene, although they had moisture peaks able to maintain an open forest. The Riparian Forest became fully installed from 4 cal kyr BP onward. Our results are in agreement with other regional studies and contribute to build a regional frame for past climatic conditions at the latitude of São Paulo.
\end{abstract}

KEYWORDS: Quaternary; palynology; riparian forest; late glacial; Holocene.

\section{INTRODUCTION}

Palynology applications in paleoenvironmental reconstruction studies have allowed us to understand the main processes involved in the distribution of species during global climatic fluctuations in the Quaternary (Bennett 1997). Studies underwent a significant change from monoproxy to multiproxy in the last decades, in which pollen grains incorporate anthropological, sedimentological and isotopic data, allowing more realistic inferences, as well as environment and climate reconstructions (Flantua et al. 2015).

In Brazil, the Quaternary researches with emphasis on paleoenvironmental reconstructions in climate change are significantly important, considering the country has the world's largest number of tropical species (IBGE 2004), consisted of

\footnotetext{
${ }^{1}$ Programa de Pós-graduação em Geociências, Instituto de Geociências, Universidade Estadual de Campinas - Campinas (SP), Brazil. E-mail: adrianacamejo@ige.unicamp.br

${ }^{2}$ Departamento de Geologia e Recursos Naturais, Instituto de Geociências, Universidade Estadual de Campinas - Campinas (SP), Brazil.E-mail: fresia@ige.unicamp

${ }^{3}$ Institut des Sciences de l'Entreprise et du Management, Université de Montpellier, Centre national de la recherche scientifique, Instituto Francês de Pesquisa para o Desenvolvimento (IRD), École Pratique des Hautes Études - Montpellier, France. E-mail: marie-pierre.ledru@ird.fr

${ }^{4}$ Centro de Pesquisa e Desenvolvimento de Recursos Genéticos Vegetais, Instituto Agronômico de Campinas - Campinas (SP), Brazil. E-mail: bernacci@iac.sp.gov.br

${ }^{*}$ Corresponding author.
}

diverse ecosystems that respond to climate changes. The forest studied here is part of this environment.

The oldest paleoclimatic record for Southeastern Brazil was identified at Colônia Crater (Ledru et al. 2015), in state of São Paulo. New studies are starting to be developed, and preliminary results indicate that sediments collected 14 meters deep present age approximately to $180 \mathrm{cal} \mathrm{kyr} \mathrm{before} \mathrm{present} \mathrm{(BP),}$ which is an important record for Brazil and South America Quaternary (Ledru et al. 2015).

Cruz Jr. et al. (2006) studied relevant paleoclimatic records for Southeastern Brazil using isotopic data in speleothems (Santana/SP and Bouteverá/SC caves). Results show climatic variations of the last $110 \mathrm{cal} \mathrm{kyr} \mathrm{BP.}$

According to the paleoenvironmental records of Serra da Mantiqueira and Núcleo Curucutu in Serra do Mar (Pessenda et al. 2009), the climate conditions were cold and humid in Southeastern Brazil near the end of the Last Glacial Maximum (LGM). The records apply for Jacareí in Paraiba do Sul River Valley (Garcia 1994, Garcia et al. 2004) and São Paulo plateau (Bissa and Toledo 2015). From the Pleistocene end to the Holocene beginning, all of studies developed in the Paulista plateau (De Oliveira et al. 2014) showed evidence of temperature increase from $18,000 \mathrm{cal}$ yr BP, with the stabilization of climatic conditions in the last 8,000 cal yr BP.

During the Holocene, the pollen record of Jacareí/SP showed cool and humid climatic conditions between 9,700 and $8,240 \mathrm{cal}$ yr BP, followed by warmer episodes between 8,240 and 3,500 cal yr BP, and then back to cooler conditions between 3,500 and 1,950 cal yr BP (Garcia et al. 2004). The pollen analyses of a fluvial terrace of Mogi Guaçu River located 
in Jataí Ecological Station (JEE) of the Forestry Institute, State of São Paulo, show drier conditions at the beginning of Holocene characterized by open-field vegetation with fire incidence (Souza et al.2013), followed by an expansion of the Riparian Forest of 2,183 cal yr. BP, as well as installation of humid climate similar to the current one (Souza et al. 2013).

Most palynological studies in Southeastern Brazil were concentrated in mountainous and coastal zones, specifically State of São Paulo, with the exception of JEE (Souza et al. 2013). Our research aims to provide new paleo-ecological data inland São Paulo related to Riparian Forest located within the Cerrado/Seasonal Semi-deciduous ecotone forest. Thus, the river course is a place of great importance, due to the main migrations of vegetal species that happen in periods of climate change at the Riparian Forests (Oliveira-Filho et al. 2015).
The studied site is located on the margins of Quilombo Stream, Santa Elisa Farm, Campinas. The study allowed characterizing vegetation and climate evolution in the last $25 \mathrm{cal} \mathrm{kyr} \mathrm{BP.}$

\section{STUDY AREA}

\section{Location}

The analyzed core was collected inside the Riparian Forest according to Carvalho et al. (2013) and located at Santa Elisa Farm in São Paulo State (22 51'22.08”S, 4705’35.50”W, $15 \mathrm{~m}$ a.s.l.). The forest covers an area of $6 \mathrm{ha}$ along the Quilombo Stream (Fig. 1) and belongs to the Agronomic Institute of Campinas (IAC, acronym in Portuguese), in the city of Campinas (São Paulo).

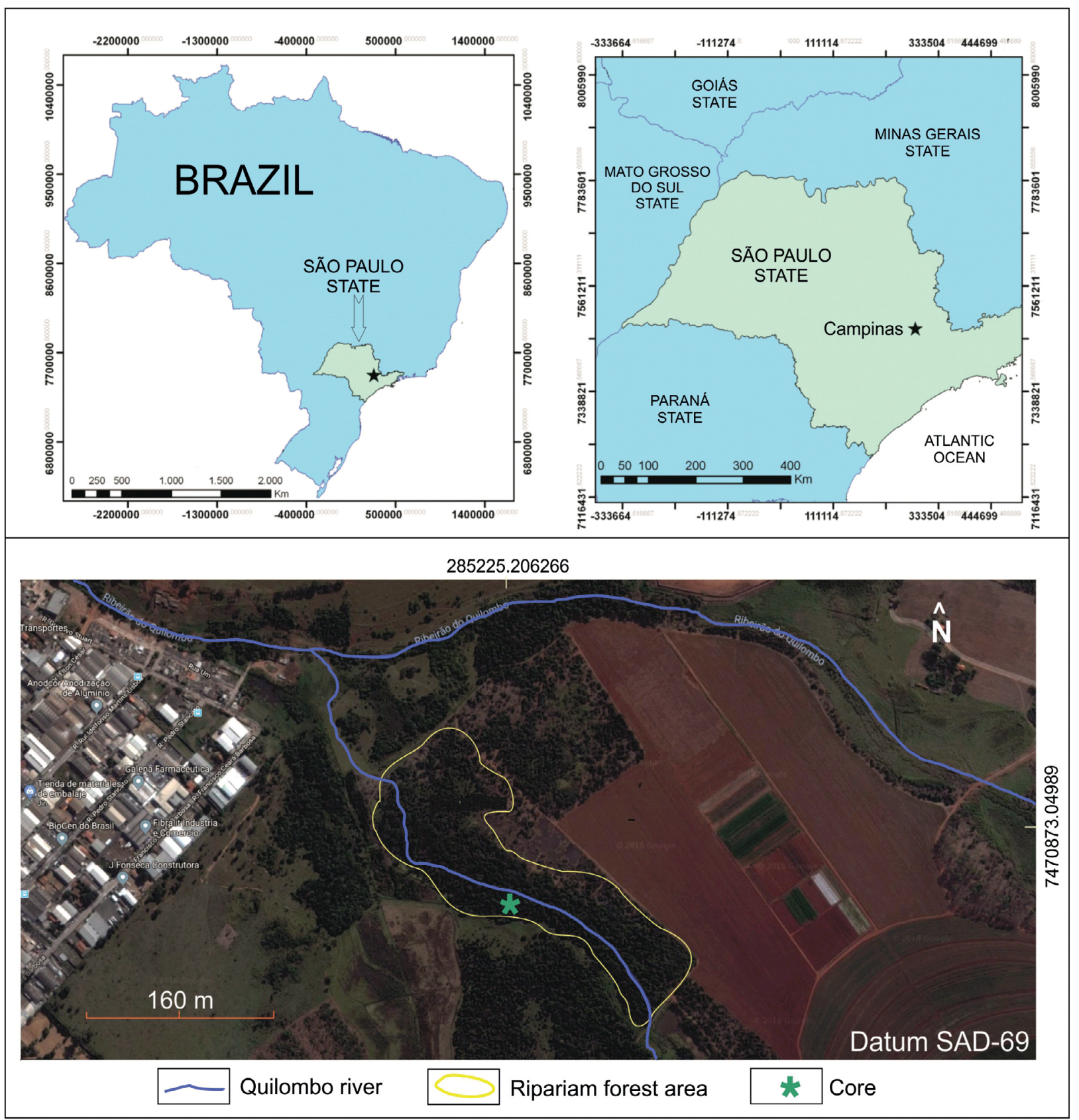

Figure 1. Map of the study area showing the core location at Santa Elisa Farm Study Site, Campinas, state of São Paulo. 


\section{Climate}

The tropical rainfall system experiences a pronounced seasonal cycle in the region of Campinas (Garreaud et al. 2009). It presents a rainy season during the austral summer (from March to October) related to the South American Summer Monsoon activity over Southeastern Brazil, and a dry season during the austral winter (September to April). The mean of annual precipitation is $1,400 \mathrm{~mm}$ and of annual temperature varies between $23.1^{\circ} \mathrm{C}$ in January and $17.1^{\circ} \mathrm{C}$ in July.

\section{Current vegetation}

Currently, vegetation in the area of Campinas shows high degree of human impact. Thus, fragments of native vegetation represent only $2.6 \%$ of the territory, which is almost entirely cultivated (Kronka et al. 2005). Vegetation at Santa Elisa Farm is a transition zone between Cerrado (Savanna) and Seasonal Semi-deciduous Forest (Penha 1998, Felfili et al. 2001, Rodrigues et al. 2004, Ferreira et al. 2007, Siqueira and Durigan 2007, Mendonça et al. 2008, Carvalho et al. 2013).

The environmental conditions that determine the distribution of Cerrado, Seasonal Semi-deciduous Sorest, and Riparian Forest are dry season length, winter temperatures, and soil drainage. Botanical surveys within the Riparian Forest described 35 families of angiosperms among 80 species, and the dominant families are: Fabaceae, Myrtaceae, Meliaceae, Lauraceae, and Rutaceae. They represent $41 \%$ of total species (Oliveira-Filho et al. 1990, Ferreira et al. 2007, Carvalho et al. 2013, Penha 1998, Rodrigues et al. 2004).

\section{MATERIALS AND METHODS}

\section{Chronology}

The chronology is based on eight radiocarbon ages (Tab. 1), three sediment samples were analyzed in the laboratory of ${ }^{14} \mathrm{C}$-AMS Beta Analytic (Miami, USA), and five samples of Humina extracted from the Laboratory of Paleo-Hydrogeology of the Institute of Geosciences from Universidade Estadual de Campinas - Unicamp (Campinas, Brazil) were analyzed in the laboratory of ${ }^{14} \mathrm{C}$ AMS - University of Georgia (Athens, USA). ${ }^{14} \mathrm{C}$ ages were calibrated using the CLAM 2.2 software (Blaauw 2010, version 2.2) with the SHCal13 calibration curve for the atmospheric southern hemisphere (Hogg et al. 2013). The result was based on a $95 \%$ probability of 2 sigma (Fig. 2 ).

\section{Stable nitrogen and carbon isotopes}

Measures of $\delta^{13} \mathrm{C}$ and $\delta^{15} \mathrm{~N}$ isotopic composition were performed at the Stable Isotope Laboratory of the Center for Nuclear Energy in Agriculture - CENA-USP (Piracicaba, Brazil). We used $1 \mathrm{~g}$ of sample for 27 levels (Tab. 2), which was distributed throughout the core (Fig. 3), as follows: in the upper $90 \mathrm{~cm}$, the sampling interval is $10 \mathrm{~cm}$; between 90 and $1.78 \mathrm{~cm}$, it is $5 \mathrm{~cm}$. Results of the isotopic ratio were expressed in $\delta$ unit (\%o) and based on the Vienna-Pee-Dee-Belemnite (PDB) international standard, referring to two determinations with an accuracy of $\pm 0,2 \%$ o (Vidotto et al. 2007).

\section{Palynological analyses}

For the palynological analysis of Santa Elisa core, we used intervals of $2 \mathrm{~cm}$ for the first $90 \mathrm{~cm}$ and $5 \mathrm{~g}$ of sediment. The samples were chemically processed following Faegri and Iversen (1989), where they were oven dried for 4 hours

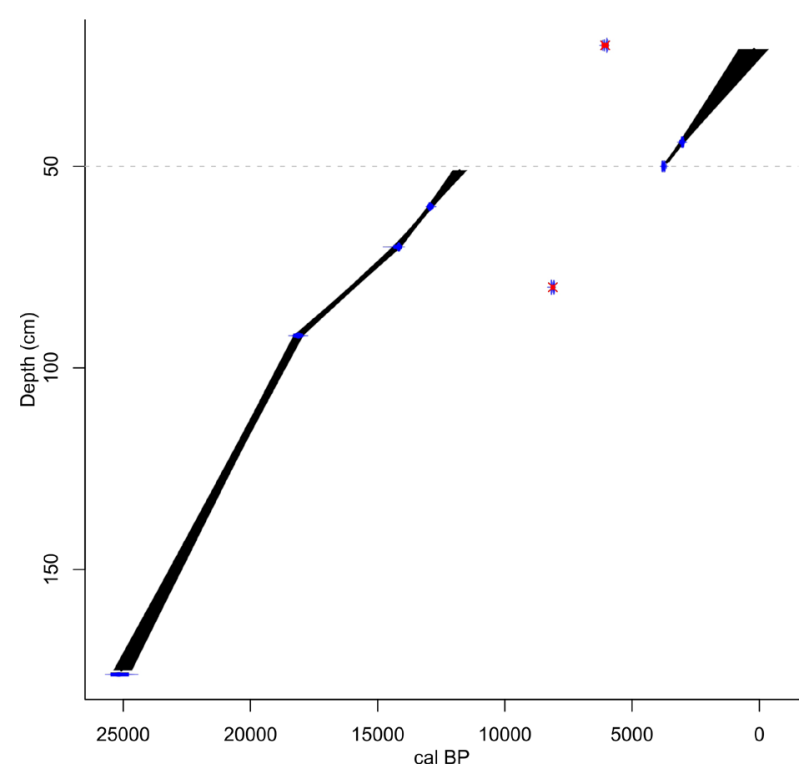

Figure 2. Age-depth model of linear interpolation based on ${ }^{14} \mathrm{C} B P$ ages with $95 \%$ confidence intervals ranging from 138 to 750 years ( 345 years on average). Ages at 80 and $20 \mathrm{~cm}$ were excluded; they are indicated with a red point considered as noise.

Table 1. Radiocarbon ages obtained from Santa Elisa Farm Core. ${ }^{14} \mathrm{C}$ dates were calibrated using CLAM 2.2 (Blaauw 2010) and SHCal13 calibration curve for the Southern hemisphere (Hogg et al. 2013).

\begin{tabular}{lcccc}
\hline Sample/Depth $(\mathbf{c m})$ & Age 14C $($ years BP) & Age 14C Cal. 2 $\delta($ years BP $)$ & 13C/12C & Laboratory code \\
\hline 20 & $5,263 \pm 27$ & $5,910-6,022$ & $-18.19 \%$ & UGAMS-28843 \\
$42-44$ & $2,890 \pm 30$ & $2,863-3,066$ & $-19.9 \%$ & BETA-314745 \\
50 & $3,479 \pm 27$ & $3,607-3,734$ & $-19.25 \%$ & UGAMS-28844 \\
60 & $11,065 \pm 31$ & $12,755-13,007$ & $-15.76 \%$ & UGAMS-28845 \\
70 & $12,277 \pm 32$ & $15,026-15,315$ & $-16.63 \%$ & UGAMS-28846 \\
80 & $7,330 \pm 23$ & $15,026-15,315$ & $-18.37 \%$ & UGAMS-28847 \\
$90-92$ & $14,910 \pm 60$ & $8,023-8,170$ & $-19.8 \%$ & BETA-314746 \\
$174-176$ & $20,850 \pm 100$ & $24,657-25,424$ & $-16.9 \%$ & BETA-314747 \\
\hline
\end{tabular}


at $\sim 60^{\circ} \mathrm{C}$. HF was added for the dissolution of silicates (leaving for 24 hours). In addition, warm $\mathrm{HCl}$ was included for colloidal silica removal, then it was washed with $10 \% \mathrm{KOH}$ for the destruction of humic acids and amorphous organic matter. The samples were dehydrated with glacial acetic acid, and finally acetolysis. An average of 10 drops of glycerin was added to the final residue.

Table 2. Results of stable isotopes analyses

\begin{tabular}{|c|c|c|c|c|}
\hline Depth $(\mathrm{cm})$ & TN (\%) & ${ }^{15} \mathrm{~N}(\%)$ & C-total (\%) & ${ }^{13} \mathrm{C}(\delta / \mathbf{p d b})$ \\
\hline 0 & 0.61 & 4.33 & 7 & -24.42 \\
\hline 10 & 0.36 & 6.13 & 4.28 & -21.68 \\
\hline 20 & 0.2 & 6.72 & 3.44 & -18.19 \\
\hline 30 & 0.16 & 7.53 & 2.64 & -18.7 \\
\hline 40 & 0.37 & 5.83 & 4.81 & -22.1 \\
\hline 50 & 0.24 & 5.55 & 4.03 & 19.25 \\
\hline 60 & 0.17 & 5.55 & 4.28 & -15.76 \\
\hline 70 & 0.1 & 5.8 & 2.02 & -16.63 \\
\hline 80 & 0.1 & 5.58 & 1.67 & -18.37 \\
\hline 90 & 0.03 & 5.27 & 0.46 & -19.69 \\
\hline 100 & 0.02 & 7 & 0.36 & -21.48 \\
\hline 104 & 0.02 & 6.22 & 0.33 & -21.53 \\
\hline 110 & 0.02 & 8.14 & 0.32 & -22.12 \\
\hline 116 & 0.02 & 7.63 & 0.33 & -22.11 \\
\hline 120 & 0.02 & 9.36 & 0.32 & -22.58 \\
\hline 124 & 0.02 & 7.88 & 0.31 & -22.64 \\
\hline 130 & 0.07 & 4.59 & 1.32 & -17.85 \\
\hline 134 & 0.08 & 5.26 & 1.21 & -18.3 \\
\hline 140 & 0.02 & 9.21 & 0.31 & -22.49 \\
\hline 146 & 0.02 & 7.28 & 0.33 & -22.26 \\
\hline 150 & 0.02 & 7.49 & 0.32 & -22.81 \\
\hline 154 & 0.02 & 7.37 & 0.28 & -21.77 \\
\hline 160 & 0.02 & 5.49 & 0.25 & -22.13 \\
\hline 166 & 0.02 & 5.68 & 0.27 & -21.03 \\
\hline 170 & 0.01 & 7.21 & 0.23 & -20.46 \\
\hline 174 & 0.02 & 6.18 & 0.14 & -17.44 \\
\hline 178 & 0.02 & 6.15 & 0.31 & -15.99 \\
\hline
\end{tabular}

After preparing the material, non-permanent microscopy slides sealed with maximal limits of residues (LMR) of histopaque fast drying glue were prepared using a residual amount of 50 microliters to calculate the concentration following the mathematical method described by Cour (1974).

About 300 pollen grains were counted. Data were expressed as a percentage of each taxon in relation to the partial sum that includes the arboreal (PA), non-arboreal/herbaceous (NPA), and indeterminate pollen grains. The rate of aquatic plants and spore grains were excluded. Spores are generally removed from the sum, due to their large production and local significance. Percentages of spores and aquatic plants were calculated as to the total sum including AP, NPA, indeterminate pollens, aquatic plants and spores.

Modern pollen rain was collected following a type of random sampling at the study site, with the total of five surface sediment samples.

A reference collection with 24 pollen types (Tab. 3) was performed for Santa Elisa Farm site considering the botanical inventory proposed by Carvalho et al. (2013). Mature flowers were collected in the herbarium of Unicamp (UEC). It was made in permanent slides with Kisser Glycerinated Gelatin (Erdtman 1971) and sealed with preheated paraffin.

\section{RESULTS}

\section{Core description}

A core of $182 \mathrm{~cm}$ length named Santa Elisa was extracted using a manual probe on the swampy banks of Quilombo Stream. Changes in color, texture and presence of plant remains were observed in the sediment as follows (Fig. 3):

- 182 to $172 \mathrm{~cm}$ : dark gray color, composed of clay and presence of iron oxides dispersed in the matrix;

- 172 to $104 \mathrm{~cm}$ : light gray color and composed of clay;

- 104 to $90 \mathrm{~cm}$ : dark gray color, composed of clay and presence of iron oxides dispersed in the matrix;

- 90 to $0 \mathrm{~cm}$ : black color, composed of clay organic sediments that are not compacted, and abundant plant remains.

\section{Chronology}

The core basis shows age of 25,040 cal yr BP. Two chronological inversions were identified: one at $80 \mathrm{~cm}$ depth with

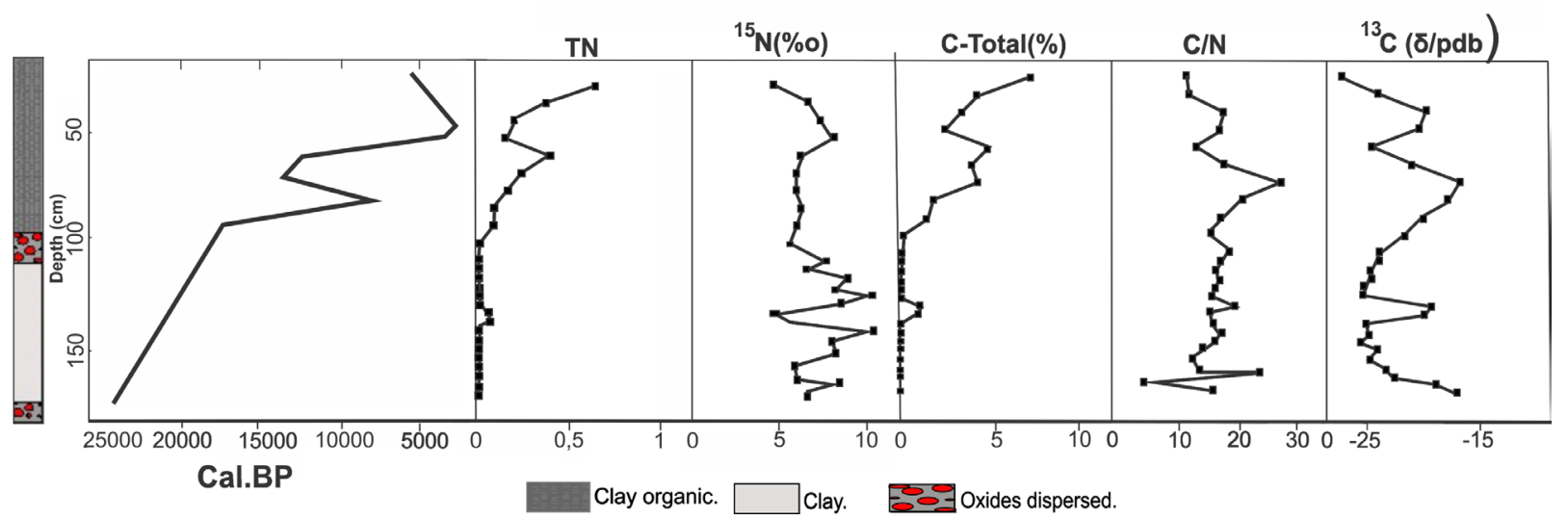

Figure 3. Lithology ages of $14 \mathrm{C} \mathrm{BP}$ and variations relative to depth of TN (\%), 15N (\%), Carbon [C-total (\%) and $13 \mathrm{C}(\delta / \mathrm{pdb})]$ and C/N. 
Table 3. List of plant species of Santa Elisa Farm from Carvalho et al. (2013) incorporated in the pollen Reference Collection at the Institute of Geosciences, Universidade Estadual de Campinas (Unicamp).

\begin{tabular}{|c|c|c|c|}
\hline Family & Species & Growth Habit & UEC Voucher \\
\hline Acanthaceae & Ruellia brevifolia (Pohl) C. Ezcurra & Shrub & 77977 \\
\hline \multirow{2}{*}{ Amaranthaceae } & Chamissoa altissima (Jacq.) Kunth & Vine & 26759 \\
\hline & Amaranthus retroflexus $\mathrm{L}$. & Herb & 40322 \\
\hline \multirow{2}{*}{ Annonaceae } & Duguetia lanceolata A.St.-Hil. & Shrub & 60172 \\
\hline & Xylopia aromatica (Lam.) Mart. & Shrub & 33281 \\
\hline Apocynaceae & Forsteronia glabrescens Müll.Arg. & Vine & 128083 \\
\hline Araliaceae & Dendropanax cuneatus (DC.) Decne. \& Planch. & Tree & 136977 \\
\hline Arecaceae & Syagrus romanzoffiana (Cham.) Glassman & Tree & 128732 \\
\hline \multirow{2}{*}{ Asteraceae } & Ageratum conyzoides $\mathrm{L}$. & Herb & 181832 \\
\hline & Erechtites valerianifolius Link ex Spreng. & Herb & 120111 \\
\hline \multirow{6}{*}{ Bignoniaceae } & Anemopaegma chamberlaynii (Sims) Burean. \& K. Schum. & Vine & 168626 \\
\hline & Handroanthus cf. heptaphyllus & Tree & 829 \\
\hline & Jacaranda micrantha Cham. & Tree & 136219 \\
\hline & Lundia obliqua Sond. & Vine & 108782 \\
\hline & Mansoa difficilis (Cham.) Bureau \& K.Schum. & Vine & 151150 \\
\hline & Pyrostegia venusta (Ker Gawl.) Miers & Vine & 132023 \\
\hline Boraginaceae & Cordia ecalyculata Vell & Tree & 997 \\
\hline Burseraceae & Protium heptaphyllum (Aubl.) Marchand. & Tree & 059437 \\
\hline Cactaceae & Pereskia aculeata Mill. & Vine & 38379 \\
\hline Celastraceae & Maytenus aquifolium Mart. & Shrub & 506771 \\
\hline Chlorantaceae & Hedyosmum brasiliense Mart. ex Miq. & Shrub & 159981 \\
\hline Clusiaceae & Calophylum brasiliensis Cambess. & Tree & 125495 \\
\hline Cucurbitaceae & Wilbrandia verticillata (Vell.) Cogn. & Vine & 3971 \\
\hline \multirow{9}{*}{ Euphorbiaceae } & Actinostemon klotzschii (Didr.) Pax. & Shrub & 110913 \\
\hline & Croton floribundus Spreng. & Tree & 105729 \\
\hline & Croton priscus Spreng. & Tree & 173231 \\
\hline & Dalechampia pentaphylla Lam. & Vine & 90366 \\
\hline & Dalechampia triphylla Lam. & Vine & 168520 \\
\hline & Pachystroma longifolium (Nees) I.M.Johnst. & Tree & 4945 \\
\hline & Sapium glandulosum (L.) Morong & Tree & 124428 \\
\hline & Sebastiania brasiliensis Spreng. & Shrub & 37556 \\
\hline & Tragia sellowiana (Baill.) Müll. Arg. & Vine & 40668 \\
\hline \multirow{3}{*}{ Leguminosae } & Anadenanthera colubrina (Vell.) Brenan & Tree & 141859 \\
\hline & Chamaecrista flexuosa (L.) Greenes. & Shrub & 119769 \\
\hline & Crotalaria paulina Schrank. & Shrub & 123546 \\
\hline \multirow{2}{*}{ Malpighiaceae } & Banisteriopsis stellaris (Griseb.) B.Gates & Vine & 163362 \\
\hline & Byrsonima sp. & Tree & 29474 \\
\hline Malvaceae & Abutilon fluviatile (Vell.) K.Schum. & Shrub & 64231 \\
\hline \multirow{2}{*}{ Melastomataceae } & Ceiba speciose (A. St.-Hil.) Ravenna & Tree & 061815 \\
\hline & Miconia chamissois Naudin & Shrub & 10718 \\
\hline \multirow{4}{*}{ Meliaceae } & Cedrela fissilis Vell. & Tree & 28836 \\
\hline & Trichilia catigua A. Juss. & Shrub & 060488 \\
\hline & Trichilia claussenii C.DC. & Shrub & 108412 \\
\hline & Trichilia elegans A. Juss. & Shrub & 49464 \\
\hline \multirow{3}{*}{ Moraceae } & Maclura tinctoria (L.) Don ex Steud. & Shrub & 62326 \\
\hline & Sorocea bonplandii (Baill.) W.C. Burger, Lanjow \& Wess. Boer. & Tree & 53173 \\
\hline & Compomanesia guazumifolia (Cambess.) O.Berg. & Tree & 151413 \\
\hline \multirow{2}{*}{ Myrtaceae } & Calyptranthes concinna DC. & Shrub & 108434 \\
\hline & Myrciaria floribunda (H.West ex Willd.) O.Berg. & Shrub & 182667 \\
\hline Sapotaceae & Chrysophyllum gonocarpum (Mart. \& Eichler) Engl. & Tree & 2071 \\
\hline Urticaceae & Boehmeria caudata Sw. & Shrub & 67612 \\
\hline Vochysiaceae & Vochysia tucanorum Mart. & Tree & 24807 \\
\hline
\end{tabular}


age of 8,096 cal yr BP, possibly derived from bioturbation, and other at $20 \mathrm{~cm}$ depth, with age of 5,966 cal yr BP, which may be attributed to carbon enrichment of older ages. We observed a hiatus between 12,881 cal yr BP and 3,670 cal yr BP (Tab. 1, Fig. 2).

\section{Total organic carbon, total nitrogen}

Total organic carbon (TOC) concentration shows progressive enrichment along the core, due to interaction between organic matter replacement and decomposition (Pessenda et al. 1996). The minimum value of TOC $(0.14 \%)$ in the $174 \mathrm{~cm}$ depth, and the maximum value of TOC (7\%) was observed in the $0-2 \mathrm{~cm}$ depth, with an average of $1.53 \%$ (Tab. 3, Fig. 3). The concentration of total nitrogen (TN) percentage (Tab. 3, Fig. 3) shows a minimum value of $0.02 \%$ at various depths of the core, ranging from 178 (25 cal kyr BP) to $140 \mathrm{~cm}(22 \mathrm{cal} \mathrm{kyr} \mathrm{BP})$, and from 124 (20 cal kyr BP) to $100 \mathrm{~cm}$ ( $18 \mathrm{cal} \mathrm{kyr} \mathrm{BP})$ with a maximum value of $0.63 \%$ in the $0-2 \mathrm{~cm}$ interval and an average of $0.10 \%$. The vegetal tissue deposition justifies the high $\mathrm{N}$ values on the core surface (Pessenda et al. 1996). Variations in nitrogen concentration follow those of carbon, as it is seen in the $30-60 \mathrm{~cm}$ $(1,308-12,924 \mathrm{cal} \mathrm{yr} \mathrm{BP})$ and $125-40 \mathrm{~cm}(20,889-2534 \mathrm{cal} \mathrm{yr}$ BP) intervals with an increase of TOC \% and TN \% content. The relationship suggests significant organic matter deposition. Nevertheless, TOC and TN tend to decrease as depth increases.

\section{$\delta^{13} \mathrm{C}$ of sedimentary organic matter}

The carbon isotope approach was used to observe changes in the distribution of $\mathrm{C}_{3}$ and $\mathrm{C}_{4}$ plant communities (Pessenda et al. 2009).

High enriched values of $\delta^{13} \mathrm{C}$ are recorded for the core base, as $-15.99 \%$, age of ${ }^{14} \mathrm{C} 20,850+-100 y r$ BP $(24,781-25,503$ calyrBP $)$, characteristic of open vegetation dominated by Poaceae, as seen in Figure 3, Table 2. A progressive impoverishment of $\delta^{13} \mathrm{C}$ is observed from the core base to $140 \mathrm{~cm}(22,144 \mathrm{cal} \mathrm{yr} \mathrm{BP})$ depth associated with a mixture of $\mathrm{C}_{3}$ and $\mathrm{C}_{4}$ plants. At $140-125 \mathrm{~cm}$ depth (22-20 cal kyr BP), an enrichment of $\delta^{13} \mathrm{C}$ was observed in the -18.3 to -17 interval. A depletion of $\delta^{13} \mathrm{C}$ with values of -22.64 to $-21.48 \%$ is observed between 125 and $100 \mathrm{~cm}(20-18$ cal kyr BP). Between 100 and $60 \mathrm{~cm}(18-12 \mathrm{cal} \mathrm{kyr} \mathrm{BP})$, the $\delta^{13} \mathrm{C}$ ranges from $-21.48 \%$ o to $-15.76 \%$ with average of $-18.38 \%$. At this stage, there are four ${ }^{14} \mathrm{C}$ ages at $90 \mathrm{~cm}$ of $14,910 \pm 60{ }^{14} \mathrm{C}$ yr BP $(15,026-15,315 \mathrm{cal} \mathrm{yr} \mathrm{BP}), 80 \mathrm{~cm}$ of $7,330 \pm 23{ }^{14} \mathrm{C}$ yr BP $(8,044-8,144 \mathrm{cal} \mathrm{yr} \mathrm{BP}), 70 \mathrm{~cm}$ of $12,277 \pm 32{ }^{14} \mathrm{C}$ yr BP $(14,047-14,376 \mathrm{cal} \mathrm{yr} \mathrm{BP})$, and $60 \mathrm{~cm}$ of $11,065 \pm 31{ }^{14} \mathrm{C}$ yr BP $(12,809-3,043 \mathrm{cal} \mathrm{yr} \mathrm{BP})$. In the $60-40 \mathrm{~cm}$ (13-3 cal kyr BP) interval, the $\delta^{13} \mathrm{C}$ values showed a trend of impoverishment with values ranging from -15.76 to $-22.1 \%$.

In the 40-cm top (2,941-3,081 cal yr BP to the present time), the $\delta^{13} \mathrm{C}$ range from -22.1 to $-24.42 \%$. At this stage, we found ${ }^{14} \mathrm{C}$ age at $20 \mathrm{~cm}$ of $5,263 \pm 27{ }^{14} \mathrm{C} \mathrm{yr} \mathrm{BP}(5,937-6,031 \mathrm{cal} \mathrm{yr} \mathrm{BP})$ that is a chronological inversion associated with carbon enrichment of older ages.

\section{Modern pollen rain}

Twenty-five pollen types representing 20 families have been identified in the five surface sediment samples in the palynological diagram (Fig. 4).
- Point 1 (Riparian Forest, 2251'21.15”S/475'37.11”W, 421 grains in total, including AP, NAP, indeterminate, and spores). The arboreal pollen grains contributed with $53 \%$ of total sum, belonging to Fabaceae [Crudia sp. (11\%), Crotalaria sp. (1\%) and Mimosa sp. (11\%)]; Euphorbiaceae [Alchornea sp. (5\%), and Euphorbia sp. (1\%)]; Chloranthaceae [Hedyosmum sp. (6\%)]; Melastomataceae/ Combretaceae (4\%); Myrtaceae (3\%); Podocarpaceae [Podocarpus sp. (3\%)], and Anacardiaceae [Lithraea sp. (2\%)]. Other families showed $1 \%$ as Apocynaceae (1\%);

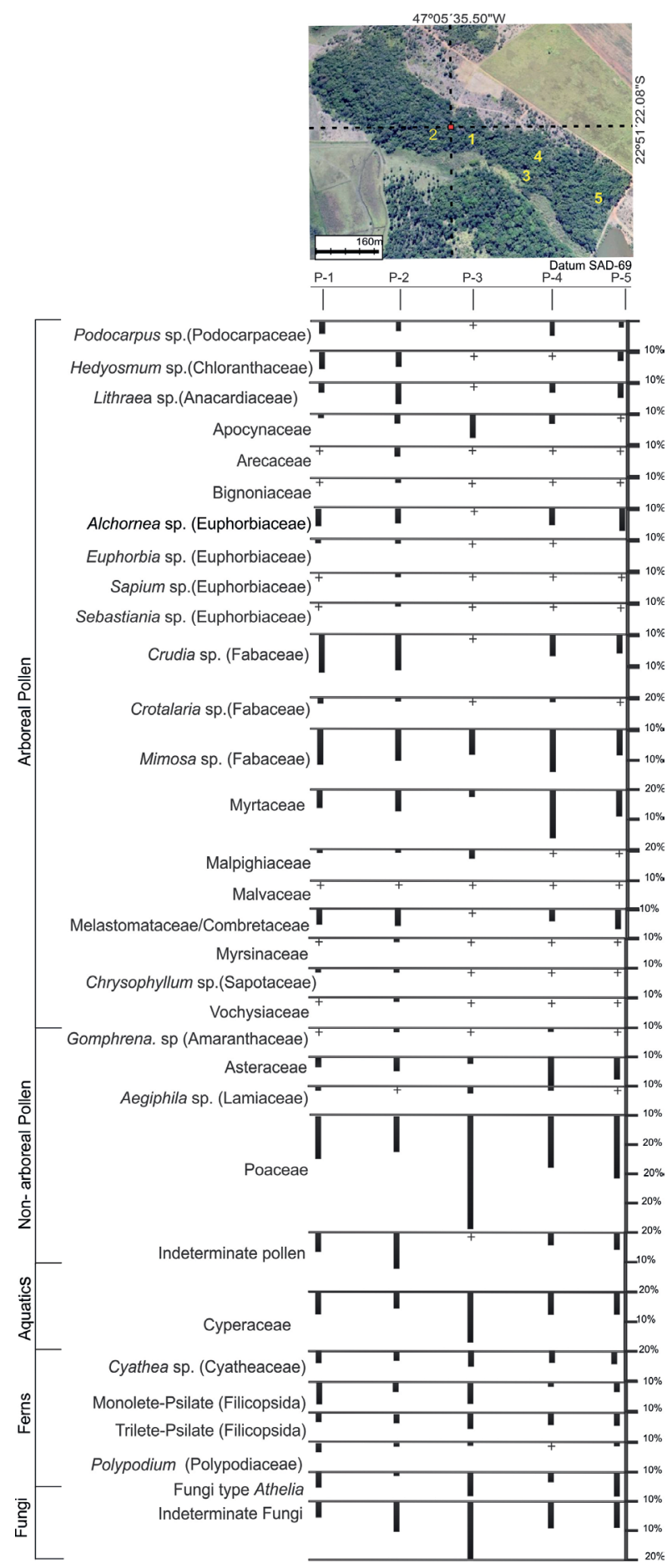

Figure 4. Diagram presenting the results of surface pollen samples collected along the riparian forest, Quilombo stream, watershed, near water course, in Campinas, São Paulo state, Brazil. (+) represents the taxa with less than $1 \%$ representation. 
Malphigiaceae (1\%) and Sapotaceae [Chrysophyllum sp. (1\%)]. Families with less than 1\% (+) were Euphorbiaceae [Sapium sp. (+), Sebastiania sp. (+)]; Arecaceae (+); Bignoniaceae (+); Malvaceae (+); Myrsinaceae (+), and Vochysiaceae $(+)$. Non-arboreal pollen grains accounted for 41\%, including Poaceae (31\%); Asteraceae (9\%); Lamiaceae [Aegiphila sp. (1\%)], and Amaranthaceae [Gomphrena sp. $(+)] .6 \%$ were indeterminate pollen grains. Finally, among aquatic plants, Cyperaceae (12\%), fern spores (15\%), Athelia fungi spores (5\%), and indeterminate fungi spores (9\%);

- Point 2 (Riparian Forest, 2251'25.82”S/475'29.66”W, 587 grains in total, including AP, NAP, indeterminate, and spores). The arboreal pollen grains contribute with $58 \%$ of total sum, belonging to Fabaceae [Crudia sp. (9\%), Crotalaria sp. (1\%), Mimosa sp. (10\%)]; Euphorbiaceae [Alchornea sp. (4\%), Euphorbia sp. (1\%), Sapium sp. (1\%), and Sebastiania sp. (1\%)]; Myrtaceae (7\%); Anacardiaceae [Lithraea sp. (7\%)]; Melastomataceae/Combretaceae (5\%); Chloranthaceae [Hedyosmum sp. (4\%)]; Arecaceae (3\%); Podocarpaceae [Podocarpussp. (2\%)], and Apocynaceae (2\%). Other families showed $1 \%$ representation as Malphigiaceae (1\%); Myrsinaceae (1\%); Vochysiaceae (1\%); Sapotaceae [Chrysophyllum sp. (1\%)], and Bignoniaceae (1\%). Malvaceae (+) was the family with less than $1 \%$. The non-arboreal pollen grains accounted for $31 \%$, with Poaceae (23\%); Asteraceae (6\%), and Amaranthaceae [Gomphrena sp. (2\%)]. Lamiaceae [Aegiphila sp. (+)] was the family with lower than $1 \%$. Indeterminate pollen grains accounted for $11 \%$. Finally, among aquatic plants, Cyperaceae ( $8 \%)$, fern spores ( $8 \%)$, Athelia fungi spores (1\%), and indeterminate fungi spores $(10 \%)$;

- Point 3 (Riparian Forest, 22051'25.74”S/4705'28.68”W, 238 grains in total, including AP, NAP, indeterminate pollen, and spores). At this point, a few palynomorphs were found with an increase of non-arboreal pollen to $81 \%$, dominated by Poaceae (72\%); Lamiaceae [Aegiphila sp. (7\%)], and Asteraceae (2\%). The AP grains decreased to $19 \%$ of the total sum, dominated by Fabaceae [Mimosa sp. (8\%)]; Apocynaceae (5\%); Melastomataceae/Combretaceae (3\%); Malphigiaceae (2\%), and Myrtaceae (1\%). Among aquatic plants, Cyperaceae family was dominant with $19 \%$, fern spores, 17\%; Athelia fungi spores, 11\%; and indeterminate fungi spores, $18 \%$;

- Point 4 (Riparian Forest, 2251’27.21”S/475’27.76”W, 371 grains in total, including AP, NAP, indeterminate pollen, and spores). The arboreal pollen grains contribute with $50 \%$ of total sum, belonging to Fabaceae [Crudia sp. (7\%), Crotalaria sp. (1\%), and Mimosa sp. (10\%)]; Euphorbiaceae [Alchornea sp. (7\%)]; Myrtaceae (15\%); Melastomataceae/Combretaceae (3\%); Podocarpaceae [Podocarpus (4\%)]; Apocynaceae (1\%), and Anacardiaceae [Lithraea sp. (1\%)]. Families with less than $1 \%(+)$ were Euphorbiaceae [Euphorbia sp. (+), Sebastiania sp. (+), and Sapium sp. (+)]; Malpighiaceae (+); Malvaceae (+); Vochysiaceae (+), and Sapotaceae [Chrysophyllum sp. (+)]. Non-arboreal pollen grains accounted for $46 \%$, with Poaceae (29\%), Asteraceae (10\%), Lamiaceae [Aegiphila sp. (2\%)], and Amaranthaceae [Gomphrena sp. (2\%)], indeterminate pollen grains (5\%). Among aquatic plants, Cyperaceae (12\%), fern spores (8\%), Athelia fungi spores (5\%), and indeterminate fungi spores (12\%);

- Point 5 (Riparian Forest, 2251’27.21”S/475’27.76”W, 421 grains in total, including AP, NAP, indeterminate, and spores). AP grains contribute with $39 \%$ of total sum, belonging to Fabaceae [Crudia sp. (4\%), and Mimosa sp. (7\%)]; Euphorbiaceae [Alchornea sp. (7\%), and Euphorbia sp. (1\%)]; Myrtaceae (8\%); Anacardiaceae [Lithraea sp. (4\%)]; Melastomataceae/Combretaceae (3\%); Chloranthaceae [Hedyosmum sp. (2\%)]; Podocarpaceae [Podocarpus sp. (2\%)]. Families with less than $1 \%(+)$ were Myrsinaceae (+); Fabaceae [Crotalaria sp. (+)]; Euphorbiaceae [Sebastiania sp. (+)]; Apocynaceae (+); Arecaceae (+); Bignoniaceae $(+)$; Malvaceae (+); Malphigiaceae (+), and Sapotaceae [Chrysophyllum sp. $(+)$ ]. NAP grains accounted for $56 \%$, with Poaceae (41\%); Asteraceae (10\%); Lamiaceae [Aegiphila sp. (2\%)], and Amaranthaceae [Gomphrena sp. (2\%)]; indeterminate pollen grains (5\%). Among aquatic plants, Cyperaceae with $15 \%$, fern spores (8\%), Athelia fungi spores $(5 \%)$, and indeterminate fungi spores (14\%).

\section{Fossil pollen}

We observed four pollen zones based on changes in pollen frequency and $\delta^{13} \mathrm{C}$ isotopic results, numbered from I (older) to IV (younger), as seen in Figure 5. Forty-three pollen types belonging to 32 families were identified in four pollen zones:

- Zone I: 15 samples, 90 and $60 \mathrm{~cm}$ depth, between $-17,770$ and $12,924 \mathrm{cal}$ yr BP. It is characterized by the absence of palynomorphs in 13 samples and low concentration in the sample at the $78-76 \mathrm{~cm}$ depth interval. The total number of pollen grains is 86 , which represents 230 pollen grains per grams of sediment. 55\% of arboreal pollen, $30 \%$ of non-arboreal pollen, and $15 \%$ of indeterminate pollen. Spores accounted for 47 to $32 \%$, and fungi from 21 to $26 \%$. Arboreal pollen grains identified in the zone belong to Malpighiaceae [Byrsonima sp. (18 to 4\%)]; Myrtaceae (13 to 8\%); Sapotaceae [Chrysophyllum sp. (11 to 8\%)]; Melastomataceae/Combretaceae (9 to 8\%); Euphorbiaceae [Euphorbia sp. (4 to 2\%), and Croton sp. (1 to 2\%)]; Vochysiaceae [Vochysia sp. (2\%)]; Arecaceae (4\%); Chloranthaceae [Hedyosmum sp. (2\%)]; Meliaceae (2\%) and Sapindaceae ( 2 to $3 \%$ ). The family that represented with less than $1 \%$ was Dilleniaceae (+). Poaceae ( 9 to 63\%) and Asteraceae (21 to $7 \%$ ) are among non-arboreal pollen grains. Cyperaceae represented the aquatic plants with 42 to $26 \%$. The $\delta^{13} \mathrm{C}$ values ranged from $-16.63 \%$ o to $-18.37 \%$, which determine a predominance of $\mathrm{C}_{4}$ plants;

- Zone II: 13 samples, 60 to $40 \mathrm{~cm}$ depth. $60 \mathrm{~cm}$ with age of $12,924 \mathrm{cal} \mathrm{yr} \mathrm{BP,} 50 \mathrm{~cm}$ with age of $3,831 \mathrm{cal} \mathrm{yr} \mathrm{BP,}$ $40 \mathrm{~cm}$ between 2,534 cal yr BP; between $60 \mathrm{~cm}$ and $50 \mathrm{~cm}$, there is a hiatus. The concentration of pollen grains was 65.7 to 487.9 with an average of 312.4 grains of pollen per gram of sediment. Arboreal pollen grains account for 42\%; non-arboreal pollen, $50 \%$; indeterminate pollen, $8 \%$; aquatic plants, $26 \%$. Spores accounted for $3 \%$, and fungi, 
29 to $15 \%$ of total pollen. Arboreal pollen grains identified in the zone are mainly represented by Apocynaceae (20 to 6\%); Dillenaceae [Tetracera sp. (1 to 11\%), Curatella americana (1\%)]; Arecaceae (7 to 4\%); Melastomataceae) Combretaceae (7\%); Myrtaceae (2 to 7\%); Sapotaceae [Chrysophyllum sp. (1 to 3\%)]; Aquifoliaceae [Ilex sp. (1 to 2\%)]; Podocarpaceae [Podocarpus sp. (1\%)]; Fabaceae [Copaifera sp. (1\%), Crudia sp. (1\%) and Mimosa sp. (1\%)]; Malvaceae [Pseudobombaxsp. (1\%)]; Caryocaraceae [Caryocar brasiliense (1\%)]; Malphigiaceae [Byrsonima sp. (1\%)]; Urticaceae [Cecropia sp. (1\%)]; Vochysiaceae [Vochysia sp. (1\%)]; Bignoniaceae (1\%); Euphorbiaceae [Euphorbia sp. (1 a 3\%), Croton sp.(1\%), Sapium sp. (1\%) and Sebastiania sp.(1\%)], and Meliaceae (1\%). The family represented with less than $1 \%$ was Anacardiaceae [Lithraea sp. $(+)$. Among non-arboreal pollen grains appear Poaceae (36 to 30\%); Asteraceae (3 to 13\%); Lamiaceae [Aegiphila sp. (3\%)]; Amaranthaceae [Gomphrena sp. (1\%)], and Caryophyllaceae (1\%). Cyperaceae (24 to 19\%) represents the aquatic taxa. The $\delta^{13} \mathrm{C}$ results showed a ${ }^{13} \mathrm{C}$ enrichment of $-22.1 \%$ o to $-18.19 \%$, as a mixture of $\mathrm{C}_{3}$ and $\mathrm{C}_{4}$ plants with predominance of $\mathrm{C}_{4}$ plants;

- Zone III: 10 samples, 40 to $20 \mathrm{~cm}$ depth, between 2,364 and $718 \mathrm{yr}$. The concentration of pollen grains ranged from 488 to 856 , with an average of 442 grains of pollen per gram of sediment. Arboreal pollen grains corresponded to $43 \%$; non-arboreal pollen, $51 \%$; indeterminate pollen, $6 \%$; and aquatic taxa, $24 \%$. Spores accounted for 8 to $7 \%$ and fungi from 36 to $25 \%$. Arboreal pollen grains identified in the zone are represented by Arecaceae (21 to 7\%); Apocynaceae (12 to 5\%); Fabaceae [Mimosa sp. (10 to $2 \%)$, Crudia sp. (2 to $1 \%$ ), and Crotalaria sp. (1\%)]; Anacardiaceae [Lithraea sp. (15 to $1 \%)$ and Tapirira sp. (1\%)]; Euphorbiaceae [Euphorbia sp. (8 to 1\%), Alchornea sp. (2 to $1 \%)$, Sapium sp. (3 to 1\%), Croton sp. (1\%), and Sebastiania sp. (2 to 1\%)]; Aquifoliaceae [Ilex sp. (2 to 1\%)]; Chloranthaceae [Hedyosmum sp. (1\%)]; Melastomatacea/Combretaceae (16 to 4\%); Myrtaceae (4 to 1\%); Urticaceae [Cecropia sp. (3\%)]; Podocarpaceae [Podocarpus sp. (2 to 1\%)]; Sapotaceae [Chrysophyllum sp. (2 to 1\%)]; Bignoniaceae (1\%); Dilleniaceae [Tetracera sp. (6 to $1 \%)$ ]; Verbenaceae [Lantana sp. (1\%)], and Malpighiaceae (4 to 1\%). Non-arboreal pollen grains are represented by Poaceae (20 to 57\%); Asteraceae (23 a 4\%); Amaranthaceae [Gomphrenasp (3 to 1\%)]; Caryophyllaceae (2 to 1\%), and Xyridaceae [Xyris sp. (3 to 1\%)]. Aquatic taxa Cyperaceae shows 36 to $24 \%$. The $\delta^{13} \mathrm{C}$ isotopic results showed ${ }^{13} \mathrm{C}$ enrichment of $-22.1 \%$ to $-18.19 \%$, as a mixture of $\mathrm{C}_{3}$ and $\mathrm{C}_{4}$ plants with predominance of $\mathrm{C}_{4}$ plants;

- Zone IV: 10 samples, 20 to $0 \mathrm{~cm}$ depth, the last 718 years. Characterized by the highest pollen concentration of Santa Elisa core, between 856 and 1,787 pollen grains per gram of sediment, and an average of 1,082 pollen grains per gram of sediment, with arboreal pollen (46\%), non-arboreal pollen (50\%), indeterminate pollen (4\%), aquatic taxa (17\%), spores ( 6 to $5 \%$ ), and fungi (36 to $25 \%$ ). Arboreal pollen grains identified in the zone are represented by Arecaceae (21 to 7\%); Fabaceae [Copaifera sp. (3 to 1\%), Crudia sp. ( 8 to $1 \%)$, Crotalaria sp. (2 to $1 \%)$, Mimosa sp. (7 to $2 \%$ ) and Myroxylon sp. (1\%)]; Anacardiaceae [Tapirira sp. (1\%) and Lithraea sp. (15 to 7\%)]; Chloranthaceae [Hedyosmum sp. (4 to 1\%)]; Euphorbiaceae [Alchornea sp. (4 to $1 \%$ ), Euphorbia sp. (2 to 1\%), Sapium sp. (1\%) and Sebastiania sp. (2 to 1\%)]; Apocynaceae (3 to 1\%); Melastomatacea)

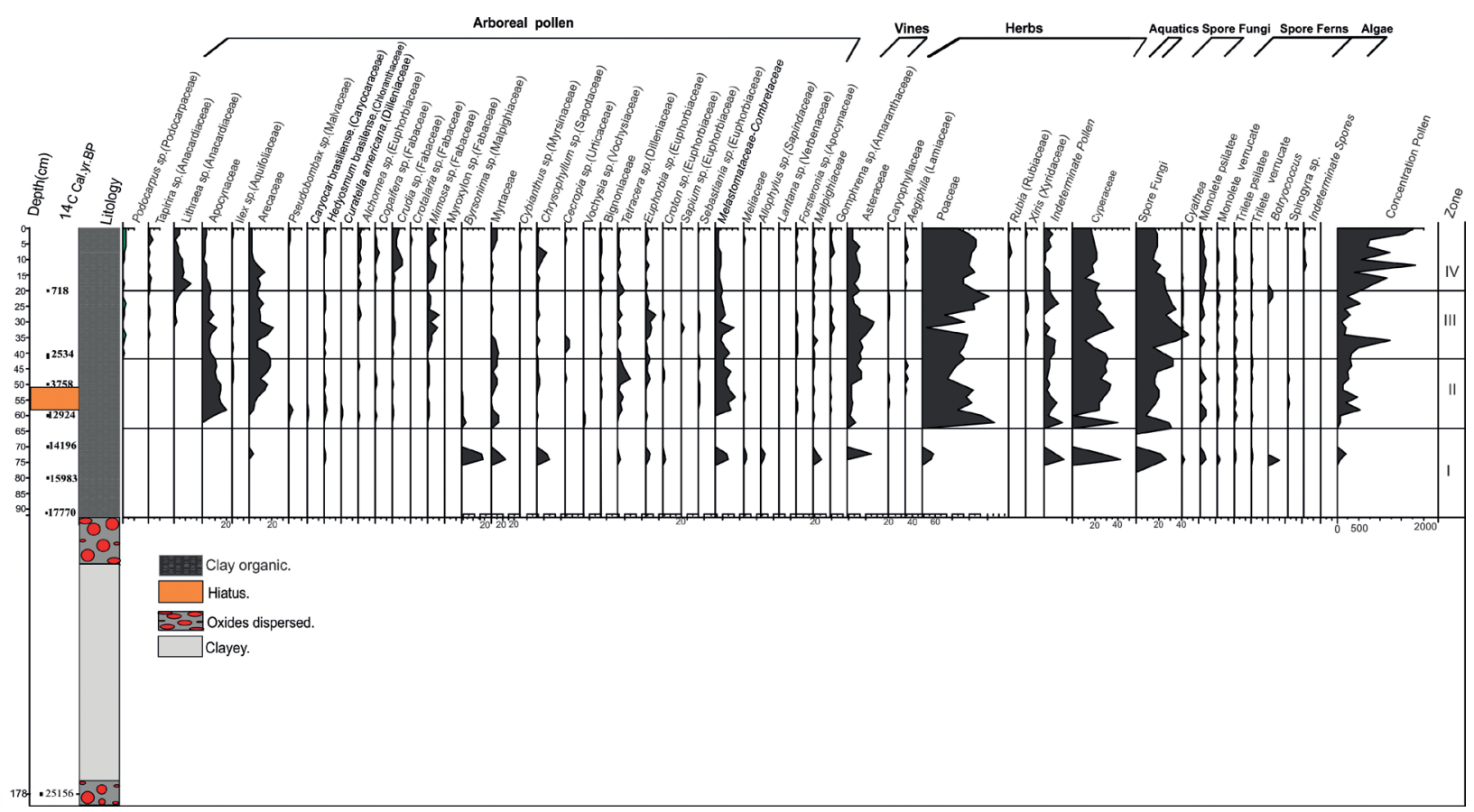

Figure 5. Fossil pollen diagram of Santa Elisa Farm core. Selected pollen and ferns taxa are expressed as percentages of the total sum (except aquatics and ferns) along a depth scale with $\delta 13 \mathrm{C}$, total concentration, $\mathrm{AP} / \mathrm{NAP}$ and four pollen zones. $14 \mathrm{C}$ dates are reported along the depth scale. 
Combretaceae (5 to 2\%); Myrtaceae (6 to 1\%); Sapotaceae [Chrysophyllum sp. (8 to 1\%)]; Podocarpaceae [Podocarpus sp. (3 to 1\%)]; Aquifoliaceae [Ilex sp. (1\%)]; Malvaceae (Pseudobombax sp. 1\%); Malpighiaceae [Byrsonima sp. (1\%)]; Myrsinaceae [Cybianthus sp. (1\%)]; Urticaceae [Cecropia sp. (1\%)]; Vochysiaceae [Vochysia sp. (1\%)]; Bignoniaceae (1 a $3 \%$ ); Dilleniaceae [Tetracera sp. (3 a $1 \%)$ ], and Meliaceae (1\%). The family with less than $1 \%$ is Euphorbiaceae [Croton sp (+)]. Non-arboreal pollen include Poaceae (30 to 47\%); Asteraceae (10 to 4\%); Amaranthaceae [Gomphrenasp (2 to 1\%)]; Xyridaceae [Xyris sp. (1\%)], and Lamiaceae [Aegiphila sp. (3 to 1\%)], and aquatic Cyperaceae (21 to $11 \%$ ). The $\delta^{13} \mathrm{C}$ isotopic results $(-18,19 \%$ at $-24,42 \%$ o indicate an impoverishment of $\delta^{13} \mathrm{C}$ with predominance of $\mathrm{C}_{3}$ plants.

\section{DISCUSSION}

\section{Modern pollen rain}

Considering the studied taxa at our site, only Podocarpaceae (Podocarpus sp.) represents gymnosperms. Podocarpus sp., a wind pollinated taxa, was not observed in the area of Santa Elisa (Carvalho et al. 2013). Its presence in surface sediment samples may be explained as being transported from nearby cities as it is widely used as an ornamental plant.

The pollen grains identified in the modern pollen rain were derived mostly from angiosperms, mainly Fabaceae, Myrtaceae, Asteraceae, Poaceae, and Cyperaceae, with a good correspondence between pollen results and botanical surveys (Carvalho et al. 2013). The pollen taxa with restricted occurrence were Vochysiaceae, Myrsinaceae, Euphorbiaceae (Sapium sp. and Sebastiania sp.), and Arecaceae.

Most of the identified pollen grains represent a broad range of habitats and belong to the physiognomies of Riparian, Cerrado, and Seasonal Semi-deciduous forests (Oliveira-Filho et al. 1990, Flora do Brasil 2012, Carvalho et al. 2013) with 25 taxa (arboreal and non-arboreal) belonging to 20 families. Of these, only 5\% have exclusive species to the Riparian Forest physiognomy (Apocynaceae, Arecaceae, Bignoniaceae Myrtaceae, and Malvaceae) observed in surface sediments and in quaternary (core) samples. An exception of Malvaceae was not found in core samples. However, Chloranthaceae (Hedyosmum sp.) associated with Seasonal Semi-deciduous Forest was found in surface, sediment, and core samples.

The remaining 95\% represent taxa inhabit either in Riparian, Cerrado or in seasonal semi-deciduous forests (Podocarpaceae, Anacardiaceae, Amaranthaceae, Bignoniaceae, Euphorbiaceae, Sapotaceae, Fabaceae, Asteraceae, Lamiaceae), and are in surface and quaternary sediments.

Not surprisingly, as all the samples are located within the forest, the pollen content of surface samples (1, 2, 4 and 5) shows little changes with dominance of arboreal pollen (50\%), as seen in Figure 4. Sample 3 demonstrates higher herbaceous taxa frequency ( $81 \%)$, due to its proximity to the limit between forest and open field, corresponding to a transition zone or ecotone.

\section{Interpretation of palynological and isotopic results}

Results of pollen and isotopic analyses of TOC, N-Total, and $\delta^{13} \mathrm{C}$ allow establishing a sequence of changes in vegetation and climate between 25 and $13 \mathrm{kyr}$ BP, and from $4 \mathrm{kyr}$ BP to the present, with a sedimentation gap between 13 and $4 \mathrm{kyr}$ BP.

\section{From 25 to 13 kyr BP}

This core basal interval presented clayey sediment and was characterized with evidence of oxidation. Isotopic data indicated low content of TOC and TN with enriched values of $\delta^{13} \mathrm{C}$ $-15.99 \%$, suggesting that around $25 \mathrm{kyr} \mathrm{BP}$ had a more open vegetation associated with drier climatic conditions than current ones. Dry conditions were not constant recording small cold humidity variations in the area.

Between 25 and $15 \mathrm{kyr} \mathrm{BP}, \delta^{13} \mathrm{C}$ shows a progressive impoverishment from $-15.99 \%$ o to $-22.49 \%$. The values reflect impoverishment associated with a mixture of $\mathrm{C}_{3}$ and $\mathrm{C}_{4}$ vegetation (Pessenda et al.2009), suggesting the forest expansion, which is likely related to in water table changes.

Between 15 and $13 \mathrm{kyr}, \mathrm{BP}$, the $\delta^{13} \mathrm{C}$ shows a predominance of $\mathrm{C}_{4}$ plants with values from $-19.69 \%$ o to $-15.76 \%$, low TOC content, and low concentration of pollen grains. The dates showed a chronological inversion of $8 \mathrm{kyr} \mathrm{BP}$ associated with a regression of the forest vegetation cover, which is likely associated with return to dry climatic conditions.

Ledru (1993) reported similar climatic conditions to this time interval from 15 to $13 \mathrm{kyr}$ BP pollen record for another environment known as Salitre, in Minas Gerais State, around $500 \mathrm{~km}$ North in the city of Campinas. In Salitre, between 15 and 12 cal kyr BP, the presence of Araucaria sp. and other mixed ombrophilous forest taxa (e.g., Ilex sp., Symplocos sp., and Drymis sp.) have been attributed to cool temperature.

At Santa Elisa, we infer water body fluctuations to explain the moisture variability between 25 and $13 \mathrm{kyr}$ BP. Pessenda et al. (2009) reinforces occurrences of groundwater level fluctuations in the countryside of São Paulo as a consequence of relative sea level variations. It indicates drier climatic conditions than today. The result is in agreement with other studies (e.g., Ledru et al. 1998, Behling 2002), which observed the predominance of dry climate in the South and Southeast Brazil at the late Pleistocene.

\section{Between 13 and 4 kyr BP}

The hiatus (Figs. 2 and 5) at 13 and 4 kyr BP found at Santa Elisa was also observed in the Northwest of São Paulo State at JEE, on a river terrace of Mogi Guaçu River (Souza et al.2013). For the JEE record, the gap ranges from 10,192 to $2,183{ }^{14} \mathrm{C} \mathrm{yr} \mathrm{BP}$, and it is interpreted as an absence of sedimentation or removal of sediments previously deposited by erosion.

At Santa Elisa, absence of sediment deposition may correspond to erosion, due to the fluvial system, a temporal functioning of Quilombo Stream or even drier climatic conditions (Ledru et al. 1998).

\section{From 4 cal yr BP to the present}

Impoverishment of $\delta^{13} \mathrm{C}$ found here may represent forest expansion with a mixture of $\mathrm{C}_{3}$ and $\mathrm{C}_{4}$ plants, and predominance 
of $\mathrm{C}_{3}$ plants (Pessenda et al. 2009). The TOC concentration shows a progressive enrichment due to the interaction between organic matter replacement and decomposition (Pessenda et al. 1996). The vegetal tissue deposition justifies high $\mathrm{N}$ values on core surface (Pessenda et al. 1996).

From 3,700 cal yr BP, a record of Cecropia sp. appear at Santa Elisa, which is pioneer taxa in secondary forests (Marchant et al. 2002). The episode likely happens due to the expansion of Riparian Forest, under warmer and moister climatic conditions. It is in agreement with other pollen records of São Paulo State, in which an increase in moisture rates was observed at 2,189 yr BP for JEE (Souza et al. 2013), and at 3,500-1,950 yr BP for Paraíba do Sul River Valley (Garcia et al. 2004).

The increase of moisture rates after three kyr BP was also observed in other Brazilian regions, such as Lagoa La Gaiba, North of Pantanal and Eastern Bolivia, where a marked expansion of tropical moist forest after three kyr BP was followed by a dry early-mid Holocene (Whitney et al. 2011, Mayle et al. 2000).

\section{CONCLUSIONS}

Our research provides new paleo data in a poorly studied region. River dynamics and their associated Riparian Forests are very sensitive to water table and climate changes. Pleistocene climatic changes showed differentiated impacts on the ecosystems in São Paulo State, due to their high landscape heterogeneity.
The paleo-ecological record of Santa Elisa farm showed drier climatic conditions than current ones and variations in moisture content between 25 and $15 \mathrm{kyr}$ BP. Erosive conditions likely due to drier climatic conditions characterize the late Pleistocene and early Holocene between 13 and 4 kyr BP. The wetter conditions only returned after $4 \mathrm{kyr}$ BP, a general trend for São Paulo State, when climatic conditions relatively like the current ones became fully established.

\section{ACKNOWLEDGEMENTS}

The authors thank the anonymous reviewers whose comments greatly improved our paper. This work was possible thanks to Fundação de Amparo à Pesquisa do Estado de São Paulo (FAPESP) funding (Process 10/16507-9 — "Water in soil morphology associated with the physiognomic gradient Riparian Forest - Cerrado in Campinas, SP”), Ms. Marina B. Carvalho, and Dr. Ricardo M. Coelho for providing the core studied here, and field support collecting the modern pollen rain. In the same way, the National Council for Scientific and Technological Development (CNPq) for the master scholarships, research fellowship awarded, and research grant (PQ), as well as UEC for the flowers provided to build the reference collection of Santa Elisa Farm. In addition, we would like to thank the Coordenação de Aperfeiçoamento de Pessoal de Nível Superior (CAPES).

\section{ARTICLE INFORMATION}

Manuscript ID: 20190040. Received on: 09/25/2018. Approved on: 22/07/2019.

A. C. wrote the first manuscript draft and prepared Figures 1 to 5. F. R. and M. L. provided advisory regarding the discussion and interpretation of palynological results, as well as the document revision, improved the manuscript through corrections and suggestions (text, figures, and tables). C. B. provided the analyzed (core) and surface samples (5), as well as information regarding the site vegetation and revised the manuscript.

Competing interests: The authors declare no competing interests.

\section{REFERENCES}

Behling H. 2002. Late Quaternary Vegetation and Climate Dynamics in Southeastern Amazonia Inferred from Lagoa da Confusão in Tocantins State, Northern Brazil. Amazoniana, 17(1):27-39.

Bennett K.D. 1997. Evolution and ecology. The pace of life. Cambridge studies in ecology. Cambridge, Cambridge University Press, 241 p.

Bissa W.M., Toledo M.B. 2015. Late Quaternary Vegetational Changes in a Marsh Forest in Southeastern Brazil with Comments on Prehistoric Human Occupation. Radiocarbon, 57(5):737-753. https://doi.org/10.2458/ azu_rc.57.18198

Blaauw M. 2010. Methods and code for "classical" age modelling of radiocarbon sequences. Quaternary Geochronology, 5(5):512-518. https:// doi.pangaea.de/10.1594/PANGAEA.873023

Carvalho M.B., Bernacci L.C., Coelho R.M. 2013. Floristic and phytosociology in a physiognomic gradient of riverine forest in Cerrado, Campinas, SP. Biota Neotropica, 13(3):110-120. http://dx.doi. org/10.1590/S1676-06032013000300014

Cour P. 1974. Nouvelle techniques de detection des flux et des retombées polliniques: étude de la sedimentation des pollens et des spores a la surface du sol. Pollen et Spores, XVI:103-141.

Cruz Jr. F.W., Burns S.J., Karmann I., Sharp W.D., Vuille M., Ferrari J.A. 2006. A stalagmite record of changes in atmospheric circulation and soil processes in the Brazilian subtropics during the Late Pleistocene. Quaternary Science Reviews, 25(21-22):2749-2761. https://doi.org/10.1016/j. quascirev.2006.02.019

De Oliveira P.E., Garcia M.J., Medeiros V.B. Pessenda L.C., Sallun A.E., Suguio K., Santos R.A. 2014. Paleoclimas e Paleovegetação do Quaternário no Estado de São Paulo, Brasil. In: Carvalho I.S., Garcia M.J., Lana C.C., Strohschoen Jr. O. (Eds.). Paleontologia: Cenários de Vida. Paleoclimas. v. 5. Rio de Janeiro, Interciência, p. 457-470.

Erdtman G. 1971. Pollen morphology and plant taxonomy: Angiosperms. 2. ed. New York, Hafner Publishing Company, 553 p.

Faegri K., Iversen J. 1989. Textbook of Pollen Analysis. Chichester, John Wiley and Sons, $328 \mathrm{p}$.

Felfili J.M., Silva Júnior M.C., Sevilha A.C., Rezende A.V., Nogueira P.E., Walter B.M., Silva F.C., Salgado M.A. 2001. Fitossociologia da vegetação arbórea. In: Felfili J.M., Silva Júnior M.C. (Eds.) Biogeografia do bioma cerrado: estudo fitofisionômico na Chapada do Espigão Mestre do São Francisco. Brasília, Universidade de Brasília, Faculdade de Tecnologia, Departamento de Engenharia Florestal, p. 35-56.

Ferreira I.C., Coelho R.M., Torres R.B., Bernacci L.C. 2007. Solos e vegetação nativa remanescente no Município de Campinas. Pesquisa Agropecuária Brasileira, 42(9):1319-1327 http://dx.doi.org/10.1590/ S0100-204X2007000900014 
Flantua S.G., Hooghiemstra H., Grimm E.M., Behling H., Bush M.B., González-Arango C., Gosling W.D., Ledru M.-P., Lozano-García S., Maldonado A., Prieto A.R., Rull V., Boxel J.H.V. 2015. Updated site compilation of the Latin American pollen database: challenging palynological research thriving Review of Palaeobotany and Palynology, 223:104-115. http://dx.doi.org/10.1016/j.revpalbo.2015.09.008

Flora do Brasil. Lista de espécies. 2012. Available at: <http:// floradobrasil.jbrj.gov.br/reflora/listaBrasil/PrincipalUC/PrincipalUC. do\#CondicaoTaxonCP>. Accessed on: Jun. 12, 2017.

Garcia M.J. 1994. Palinologia de turfeiras Quaternárias do médio Vale do Rio Paraíba do Sul, Estado do São Paulo. PhD Thesis, Universidade de São Paulo, São Paulo, 354 p.

Garcia M.J., De Oliveira P.E., Siqueira E., Fernandes R.S. 2004. Holocene vegetational and climatic records from the Atlantic rainforest belt of coastal state of São Paulo, SE Brazil. Review of Paleobotany and Palinology, 131(3-4):181-199. http://dx.doi.org/10.1016/j. revpalbo.2004.03.007

Garreaud R., Vuille M., Compagnucci R., Marengo J. 2009. Present-day South American Climate. Palaeogeography, Palaeoclimatology, Palaeoecology, 281(3-4):180-195. http://dx.doi.org/10.1016/j.palaeo.2007.10.032

Hogg A.G., Hua Q. Blackwell P.G., Niu M., Buck C.E., Guilderson T.P., Heaton T.J., Palmer J.G., Reimer P.J., Reimer R.W., Turney C.S, Zimmerman S.R. 2013. IntCal13 and Marine13 Radiocarbon Age Calibration Curves 0-50,000 Years cal BP. Radiocarbon, 55(4):1889-1903. http://dx.doi. org/10.2458/azu_js_rc.55.16783

Instituto Brasileiro de Geografia e Estatística (IBGE). Mapa de Biomas do Brasil. Instituto Brasileiro de Geografia e Estatística, 2004. Available at: <http://www.igfe.gov.br/mapas/>. Accessed on: Sept. 02, 2019.

Kronka F., Nalon M., Matsukuma C. 2005. Inventário florestal da vegetação natural do Estado de São Paulo. São Paulo, Secretaria do Meio Ambiente; Instituto Florestal, $200 \mathrm{p}$

Ledru M.P. 1993. Late Quaternary Environmental and Climatic Changes in Central Brazil. Quaternary Research,39(1):90-98. https://doi.org/10.1006/ qres.1993.1011

Ledru M.P., Reinhold W., Ariztegui D., Bard E., Crósta P.A., Riccomini C., Sawakuchi A. 2015. Why deep drilling in the Colônia Basin (Brazil)? Workshop Reports. Scientific Drilling, 20:33-39. http://dx.doi.org/10.5194/ sd-20-33-2015

Ledru M.P., Salgado-Labouriau M.L., Lorscheitter M.L. 1998. Vegetation dynamics in southern and central Brazil during the last 10,000 yr B.P. Review of Palaeobotany and Palynology, 99(2):131-142. https://doi.org/10.1016/ S0034-6667(97)00049-3

Marchant R., Almieda L., Behling H., Berrio J.C., Bush M., Cleef A., Duivenvoorden J., Kappelle M., De Oliveira P., Oliveira-Filho A., LozanoGarcía S., Hooghiemstra H., Ledru M.-P., Ludlow-Wiechers B., Markgraf V., Mancini V., Paez M., Prieto A., Salgado-Labouriau M.L. 2002. Distributional and ecological information concerning the pollen taxa of Latin America. Review of Palaeobotany and Palynology, 121(1):1-75. https://doi. org/10.1016/S0034-6667(02)00082-9
Mayle F.E., Burbridge R., Killeen T.J. 2000. Millennial-Scale Dynamics of Southern Amazonian Rain Forests. Science. 290(5500):2291-2294. https:// doi.org/10.1126/science. 290.5500.2291

Mendonça R.C., Felfili J.M., Walter B.M., Silva Junior M.C., Rezende A.V., Filgueiras T.S., Silva P.E., Fagg C.W. 2008. Flora vascular do Bioma Cerrado: Checklist com 12.356 espécies. In: Sano S.M., Almeida S.P., Ribeiro J.F. (Eds.). Cerrado: ecologia e flora, v. 2. Brasília: Embrapa Cerrados/Embrapa Informação Tecnológica. $421 \mathrm{p}$.

Oliveira-Filho A.T., Budke J.C., Jarenkow J.A., Eisenlohr P.V., Neves D.R. 2015. Delvind into variations in tree species composition and richness across South American subtropical Atlantic and Pampean forest. Journal of Plant Ecology, 8(3):242-260. https://doi.org/10.1093/jpe/rtt058

Oliveira-Filho A.T., Ratter J.A., Shepherd G.J. 1990. Floristic Composition and Community Structure of a Central Brazilian Gallery Forest. Flora, 184(2):103-117. https://doi.org/10.1016/S0367-2530(17)31598-0

Penha A.S. 1998. Propagação vegetativa de espécies arbóreas a partir de raízes gemíferas: representatividade na estrutura fitossociológica e descrição dos padrões de rebrota de uma comunidade florestal, Campinas, São Paulo. MS Dissertation, Universidade Estadual de Campinas, Campinas, $114 \mathrm{p}$.

Pessenda L.C., Aravena R., Melfi A., Telles E.C.C., Boulet R., Valencia E.P.E., Tomazello M. 1996. The use of carbon isotopes (C-13, C-14) in sol to evaluate vegetation changes during the holoceno in Central Brazil. Radiocarbon, 38(2):191-201. https://doi.org/10.1017/S0033822200017562

Pessenda L.C., De Oliveira P., Mofatto M., De Medeiros V., Garcia R., Aravena R., Bendassoli J., Leite A., Saad A., Etchebehere M.L. 2009. The evolution of a tropical rainforest/grassland mosaic in southeastern Brazil since 28,000 ${ }^{14} \mathrm{C}$ yr BP based on carbon isotopes and pollen records. Quaternary Research, 71(3):437-452. https://doi.org/10.1016/j.yqres.2009.01.008

Rodrigues R.R., Torres R.B., Matthes L.A.F., Penha A.S. 2004. Tree Species Sprouting from Root Buds in a Semideciduous Forest Affected by Fires. Brazilian Archives of Biology and Technology, 47(1):127-133. http://dx.doi. org/10.1590/S1516-89132004000100017

Siqueira M.F., Durigan G. 2007. Modelagem da distribuição geográfica de espécies lenhosas de cerrado no Estado de São Paulo. Revista Brasileira de Botânica, 30(2):233-243. http://dx.doi.org/10.1590/ S0100-84042007000200008

Souza M.M., Branco F.R., Jasper A., Pessenda L.C. 2013. Evolução paleoambiental holocênica da porção nordeste do estado de São Paulo, Brasil. Revista Brasileira de Paleontologia, 16(2):297-308. http://dx.doi. org/10.4072/rbp.2013.2.10

Vidotto E., Pessenda L.C., Ribeiro A.S., Freitas H.A., Bendassoli J.A. 2007. Dinâmica do ecótono floresta-campo no Sul do Estado do Amazonas no Holoceno, através de estudos isotópicos e fitossociológicos. Acta Amazônica, 37(3):389-404. http://dx.doi.org/10.1590/S0044-59672007000300010

Whitney B.S., Mayle F.S., Punyasena S.W., Fitzpatrick K.A., Burn M.J. Guillen R., Chavez E., Mann D., Pennington E.T., Metcalfe S.E. 2011. A 45 kyr palaeoclimate record from the lowland interior of tropical South America. Palaeogeography, Palaeoclimatology, Palaeoecology, 307(1-4):177-192. https://doi.org/10.1016/j.palaeo.2011.05.012 